\title{
Schistosoma mansoni AND OTHER LARVAL TREMATODES IN Biomphalaria tenagophila (PLANORBIDAE) FROM GUARULHOS, SÃO PAULO STATE, BRAZIL
}

Josué DE MORAES(1,2), Marcos Paulo NASCIMENTO DA SILVA(1), Fernanda Pires OHLWEILER(3) \& Toshie KAWANO(1,2)

\begin{abstract}
SUMMARY
A total of 909 Biomphalaria tenagophila were collected from two areas in Guarulhos (Metropolitan area of São Paulo, São Paulo State, Brazil) to assess larval trematode infections. In all collection sites, only this species was found and $183(20.13 \%)$ harbored trematode infections. In these collections, four morphologically distinguishable types of cercariae were identified by confocal microscopy. Xiphidiocercaria (Cercaria lutzi) was the most common type of cercaria recovered, contributing $76.5 \%$ of all infections. Schistosoma mansoni cercariae were recovered and comprised the total of $13.11 \%$. Strigea cercaria (Cercaria caratinguensis) and Brevifurcate pharyngeate Clinostomatoide cercaria (Cercaria ocellifera) contributed $8.33 \%$ and $2.22 \%$ of all infections, respectively. Double infections ( $S$. mansoni and C. lutzi) were found in twelve snails, contributing $6.55 \%$ of all infections. In all sites studied, small vertebrates were found in snail habitats and it was observed human contact with the water. The presence of trematode infected snails in large cities has public health implications. It further provides a starting point for some comprehensive studies on snail-related aspects of transmission and biology of trematode of medical and veterinary importance.
\end{abstract}

KEYWORDS: Biomphalaria tenagophila; Schistosoma mansoni; Schistosomiasis; Larval trematodes; Guarulhos; Brazil.

\section{INTRODUCTION}

Trematodes are parasitic flatworms of great medical and veterinary importance. Among trematodes, Schistosoma species are the most important for public health ${ }^{17}$. Schistosomiasis is endemic in tropical and subtropical regions. It is estimated that 200 million people are infected worldwide, and about 600 million are at risk ${ }^{8}$. In Brazil six to eight million people are infected and 26 million are at risk of Schistosoma mansoni infection. Currently, transmission occurs in 19 states and Federal District ${ }^{1}$.

The extensive distribution of the intermediate hosts, Biomphalaria species, in Brazil gives the schistosomiasis an expansive characteristic. Currently 23 trematode families represented by 16 kinds of cercariae were revealed and Biomphalaria tenagophila (Orbigny, 1835) lodges the most diversity of cercariae ${ }^{4}$.

It is known that some trematodes may act as regulators of snail populations $s^{21,24}$. Studies on larval trematodes can also reveal the possible existence of certain trematode species that could be manipulated to achieve biological control of snail-transmitted diseases ${ }^{9,12}$.

In the São Paulo State, schistosomiasis is still a public health problem $^{33,39}$. Biomphalaria tenagophila is the second most important specie related to the transmission of schistosomiasis in Brazil and in São Paulo State it is the most important intermediate host ${ }^{36}$. The relationship between the distribution of planorbids and schistosomiasis occurrence was observed in some studies ${ }^{10,31,35,36,37,38}$. Studies on the distribution of snails and presence of $S$. mansoni cercaria in metropolitan areas of São Paulo, is very scarce. Besides, the presence of cercariae trematodes and its morphological description was less examined. Furthermore, in Guarulhos city (São Paulo State) the prevalence and the snails infected with $S$. mansoni or other trematodes have never been studied.

Morphological characteristics as number, size and position of body suckers, shape and relative dimensions of the cercarial tail and the presence or absence of various specialized surface structures like stylet and eyespot, are important for identification of trematode. Indeed, identification of cercarial specimens is generally possible using morphological criteria alone and the term Cercaria may be regarded as a generic name for all described species of cercariae ${ }^{15,32}$.

The aim of this study was to investigate the distribution of Biomphalaria snails and describe the focus of trematodes of medical and veterinary importance in outskirts of Guarulhos city; in addition, some cercariae were identified by confocal microscopy.

(1) Laboratory of Parasitology, Instituto Butantan, Av. Vital Brasil 1500, 05503-900 São Paulo, SP, Brazil.

(2) Biotechnology, Instituto de Ciências Biomédicas, Universidade de São Paulo, São Paulo, SP, Brazil.

(3) Laboratory of Malacology, Superintendência de Controle de Endemias, São Paulo, SP, Brazil.

Correspondence to: Toshie Kawano, Fax: +55.11.3726-1505. Tel: +55.11.3726-7322/2281. E-mail: toshie@butantan.gov.br 


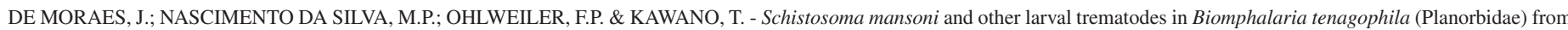
Guarulhos, São Paulo State, Brazil. Rev. Inst. Med. trop. S. Paulo, 51(2): 77-82, 2009.

\section{MATERIALS AND METHODS}

Description of the area: The municipality of Guarulhos is situated in the metropolitan area of São Paulo (São Paulo State), Brazil. Located at $17 \mathrm{~km}$ from São Paulo capital and occupying an area of $341 \mathrm{~km}^{2}$, its climate is damp subtropical with temperature average of $19^{\circ} \mathrm{C}$ and its mean altitude is around $850 \mathrm{~m}$ above sea level with mean annual rainfall of 1440 $\mathrm{mm}$. Guarulhos is the second largest city in São Paulo State concerning to population (about 1.3 million of inhabitant) and economic power ${ }^{18}$.

This study was carried out in outskirts of Guarulhos City, specifically in districts of Bonsucesso and Vila Sadokim with more than 70,000 inhabitant ${ }^{28}$. These districts are nearby the most important Brazilian free-way road (between km 206 and 208 Rodovia Presidente Dutra, BR-116) which connect the states of São Paulo and Rio de Janeiro (Fig. 1). In spite of having a large urban area, these districts are characterized by many swampy areas and mainly streams rain- or man-made. Besides, many houses are around irrigation ditches with vegetables plantation. Therefore, we have investigated the presence of snails of Biomphalaria in streams, marsh areas, drainage and sewage ditches, flood areas, ponds and irrigation ditches in urban perimeter of the outskirts districts of Guarulhos.

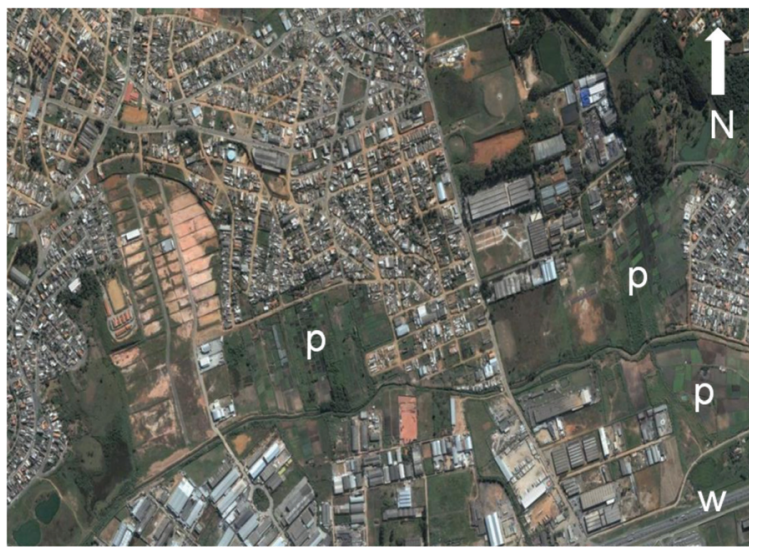

Fig. 1 - Partial aerial view of Bonsucesso and Vila Sadokim districts, showing urban area and plantation of vegetables (p). Free-way road (Rodovia Presidente Dutra, BR-116) is also indicated (w). Photo captured of Google Earth software (http://www.earth.google.com). The direction of North $(\mathrm{N})$ is indicated by an arrow.

Collect and identification of Biomphalaria: The snails were collected from April to August 2007 either using a kitchen sieve mounted on a $1.5 \mathrm{~m}$ long wooden handle or captured directly using gloved hands ${ }^{27}$. In each local containing snail at least three different collections were made. Living molluscs were kept at $25^{\circ} \mathrm{C}$ under laboratory conditions for a month in aquaria containing dechlorinated tap water and, at the bottom, a thin layer of a 2:1 mixture of screened soil and ground oyster shells as source of mineral nutrients, fed with fresh lettuce leaves. The snails were fixed in Railliet-Henry's fluid and dissected under a stereomicroscopy for specific identification.

Identification of cercariae: All snails were put individually into the wells of 12-well tissue culture plates (Nalg Nunc International) and exposed to artificial light (for two to three hours) for five days intervals under a stereomicroscopy to determinate the possible infection with trematode larvae. In addition, snails were individually pressed between two glass plates to detect the presence of larvae ${ }^{40}$. The cercariae were identified under light microscopy and confocal microscopy (Laser Scanning Microscopy, LSM 510 META, Zeiss) at $488 \mathrm{~nm}$ (exciting) and $505 \mathrm{~nm}$ (emission) based on the morphological characteristics, swimming behavior and resting position as described by FRANDSEN \& CHRISTENSEN ${ }^{15}$, SCHELL ${ }^{32}$ and RUIZ ${ }^{29,30}$.The larvae were observed "in vivo" and fixed in Formalin-acetic-alcohol solution (F.A.A.). Moreover, some trematode larvae were stained with hemalumen and mounted in Canada balsam.

\section{RESULTS}

The total of 909 B. tenagophila was collected in stream, irrigation ditch and puddle of collection site in districts of Bonsucesso and Vila Sadokim. Four kinds of cercariae were found in B. tenagophila: Xiphidiocercaria (Cercaria lutzi), Strigea (Cercaria caratinguensis), Brevifurcate pharyngeate Clinostomatoide (Cercaria ocellifera), and Brevifurcate apharyngeate (Cercaria blanchardi, larval form of the Schistosoma mansoni).

Cercaria lutzi (Ruiz, 1943) (Fig. 2): Body oval (130 $\mu \mathrm{m}$ - $145 \mu \mathrm{m} \mathrm{x}$ $95 \mu \mathrm{m}-115 \mu \mathrm{m})$ and tail unforked $(100 \mu \mathrm{m}-155 \mu \mathrm{m})$. Oral sucker large (37-51) with stylet long, central and well developed, (17 $\mu \mathrm{m}-22 \mu \mathrm{m})$; ventral sucker $(22 \mu \mathrm{m}-35 \mu \mathrm{m})$ between posterior and middle of body, smaller than oral sucker. Body surface covered with small spines towards anterior side. Eyespots absent. When cercariae were released from snail, they swam for 1-2 days and showed negative phototactism behavior.
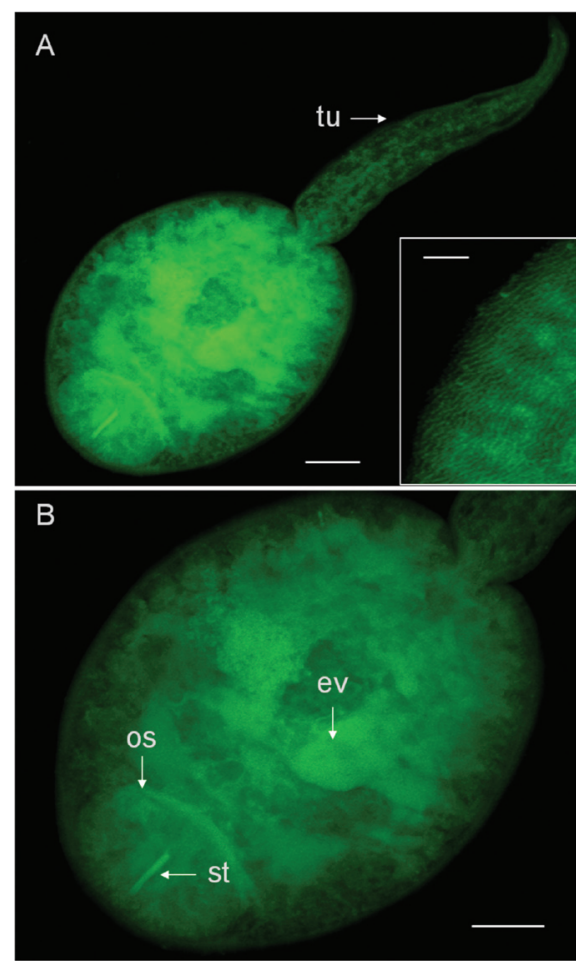

Fig. 2 - General morphology of Cercaria lutzi. A: General view showing body and tail unforked (tu) $($ bar $=20 \mu \mathrm{m})$. Inset: Detail of body surface $($ bar $=10 \mu \mathrm{m})$. B: Detail of oral sucker $(\mathrm{os})$ with stylet well developed (st) and excretory vesicle (ev) (bar $=20 \mu \mathrm{m})$. 


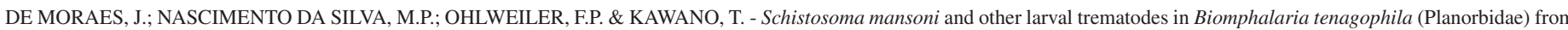
Guarulhos, São Paulo State, Brazil. Rev. Inst. Med. trop. S. Paulo, 51(2): 77-82, 2009.

Cercaria caratinguensis (Ruiz, 1953) (Fig. 3): Body elongate (120 $\mu \mathrm{m}-130 \mu \mathrm{m} \times 45 \mu \mathrm{m}-55 \mu \mathrm{m})$ and tail forked $(140 \mu \mathrm{m}-145 \mu \mathrm{m})$, tail stem with furcae very long $(150 \mu \mathrm{m}-195 \mu \mathrm{m})$. Body surface covered with spines. Oral sucker oval $(25 \mu \mathrm{m}-35 \mu \mathrm{m})$; ventral sucker round (29 $\mu \mathrm{m}-30 \mu \mathrm{m})$ well developed, near middle of body. Eyespots present ( 7 $\mu \mathrm{m}-8 \mu \mathrm{m})$. Caudal bodies present in the tail stem. The cercariae emerged in large numbers and its swimming behaviour seems $S$. mansoni cercariae. After cercariae emerged first time $B$. tenagophila continue for three to four days without presence of light.
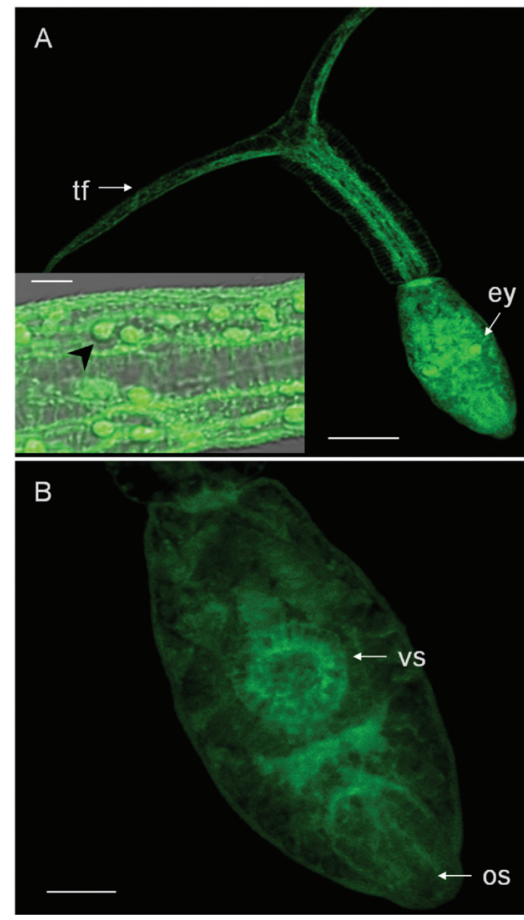

Fig. 3 - General morphology of Cercaria caratinguensis. A: General view showing body with eyespots (ey) and tail forked (tf) (bar $=50 \mu \mathrm{m})$. Inset: Detail of caudal bodies (arrowheads) (bar $=5 \mu \mathrm{m})$. B: Detail of ventral sucker (vs) and oral sucker $(\mathrm{os})(\mathrm{bar}=20 \mu \mathrm{m})$.

Cercaria ocellifera (Lutz, 1917) (Fig. 4): Body elongate (126 $\mu \mathrm{m}$ - $132 \mu \mathrm{m} \times 32 \mu \mathrm{m}-42 \mu \mathrm{m})$ and tail forked. Tail stem $(255 \mu \mathrm{m}-315$ $\mu \mathrm{m})$ much longer than furcae $(70 \mu \mathrm{m}-120 \mu \mathrm{m})$. Oral sucker round or oval $(30 \mu \mathrm{m}-32 \mu \mathrm{m})$; ventral sucker small and not easily observable. Body covered with small spines; a pair of eyespots prominent ( $6 \mu \mathrm{m}$ $8 \mu \mathrm{m})$. Tail covered with spines, much longer than spines of body; caudal bodies present in the tail. Very few cercariae (1 to 3) emerged of one $B$. tenagophila specime. No phototactism was observed.

Cercaria blanchardi (Pirajá da Silva, 1912), larval form of $S$. mansoni (Fig. 5). Body elongate $(125 \mu \mathrm{m}-130 \mu \mathrm{m}$ x $72 \mu \mathrm{m}-76 \mu \mathrm{m})$ and tail forked. Tail stem $(245 \mu \mathrm{m}-270 \mu \mathrm{m})$ much longer than furcae $(110 \mu \mathrm{m}-118 \mu \mathrm{m})$. Oral sucker elongate $(35 \mu \mathrm{m}-45 \mu \mathrm{m})$ and ventral sucker round or oval $(17 \mu \mathrm{m}-20 \mu \mathrm{m})$ near posterior of body. Oral sucker longer than ventral sucker.

The most common type of cercaria recovered was the Xiphidiocercaria (Cercaria lutzi), which contributed $76.5 \%$ of all larval trematode infections recorded and it was found in all type of collection site. This

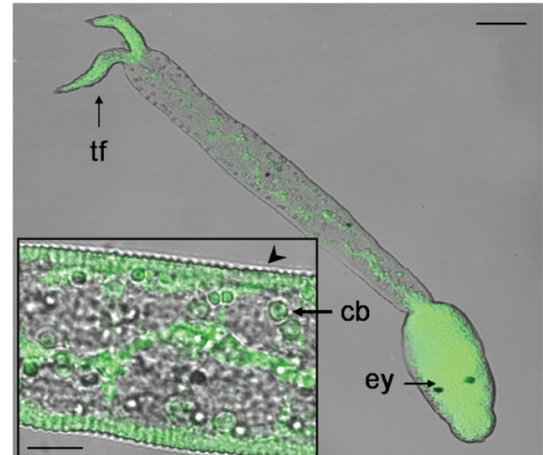

Fig. 4 - General morphology of Cercaria ocellifera. General view showing body with eyespots (ey) and tail forked (tf) (bar $=50 \mu \mathrm{m})$. Inset: Detail of caudal bodies $(\mathrm{cb})$ and body surface (arrowheads) (bar $=10 \mu \mathrm{m})$.

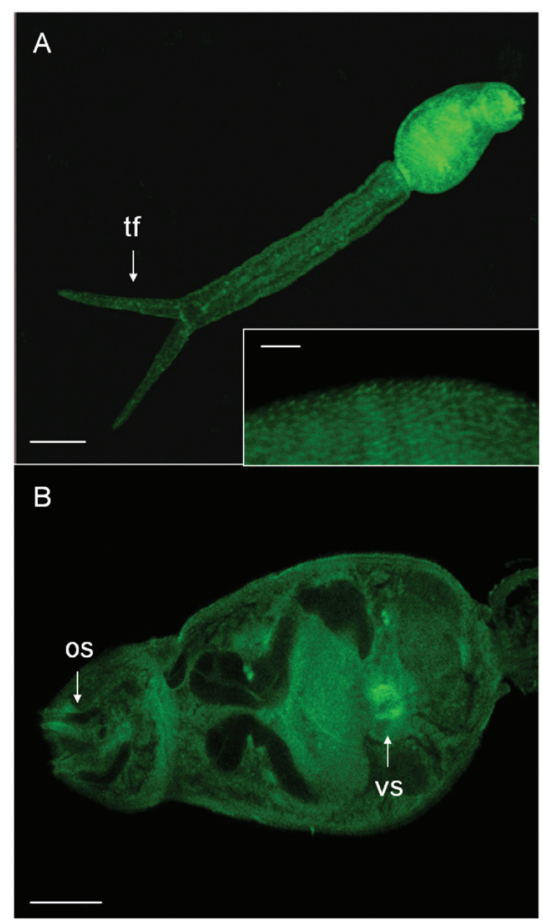

Fig. 5 - General morphology of Cercaria blanchardi, larval form of the Schistosoma mansoni. A: General view showing body and tail forked $(\mathrm{tu})(\mathrm{bar}=50 \mu \mathrm{m})$. Inset: Detail of body surface (bar $=5 \mu \mathrm{m})$. B: Detail of oral sucker (os) and ventral sucker (vs) (bar $=20 \mu \mathrm{m})$.

was followed by the Brevifurcate apharyngeate cercaria (S. mansoni), which accounted for $13.11 \%$ of infections, Strigea cercaria (Cercaria caratinguensis), $8.33 \%$ of infections, while Brevifurcate pharyngeate Clinostomatoide cercaria (Cercaria ocellifera) only contributed $2.22 \%$ of all larval trematode infections recorded. Double infections of cercariae ( $S$. mansoni and C. lutzi) were found in twelve snails.

The overall prevalence of cercariae species infections in the habitats ranged between 1.14 and $32.72 \%$. The prevalence was particularly high in Puddle localized in Bonsucesso district (32.72\%) and particularly low in irrigation ditch located in same place. The widespread of $S$. mansoni was $7.54 \%$ and only occurred in stream Vila Sadokim (Table 1). 


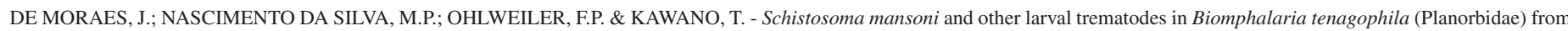
Guarulhos, São Paulo State, Brazil. Rev. Inst. Med. trop. S. Paulo, 51(2): 77-82, 2009.

In all places studied the presence of some vertebrates was observed, the most common were amphibians, rats and many species of birds (Table 1). The human contact with the water was observed in all habitats, especially in irrigation ditches.

\section{DISCUSSION}

Geographical distribution and parasitic detection in mollusks are very important to the control on medical veterinary epidemiological concern. Snails survey was carried out in the Guarulhos city, specifically in Bonsucesso and Vila Sadokim districts, and the presence of $B$. tenagophila harboring different types of larval trematode was verified.

In all, four larval forms were found in B. tenagophila. Results indicate a low overall infection rate of snails with larval trematodes. This is in line with findings from other studies, $2,7,21,27$. The low infection prevalence could be attributed to a direct consequence of high rates of parasite-induced mortality or resistance to infection acquired by host ${ }^{34}$. Besides, this could also be due to stream and water pressure, that difficult the contact between miracidia and snails ${ }^{7,27}$.

The lesser diversity of snails infected with cercariae types in the Southeastern Region was observed in São Paulo, despite the findings carried by RUIZ ${ }^{29,30}$, MACHADO et al. ${ }^{22}$ and CARVALHO et al. ${ }^{5}$. In this State, B. tenagophila was found with six of cercariae types, and Xiphidiocercariae and Strigea are most frequent. Indeed, in the study, the dominant of type cercaria was Xiphidiocercaria and it was identified as Cercaria lutzi according to RUIZ ${ }^{29}$. Due to the absence of dorso-ventral finfold in the tail, this cercarie belongs to Armatae of the Plagiorchiidae family, intestinal parasites in all groups of vertebrates ${ }^{15,29}$. According to RUIZ $^{29}$ this cercaria is probably a larval form of Pneumonoeces neivai (Travassos \& Artigas, 1927), that have as definitive host mainly frog of genus Leptodactylus. In four places of the collection site we observed several amphibians that probably are hosts of these helminths parasites. Xiphidiocercaria is common in Brazil and other countries. However, in the São Paulo State it was found only in Santos coastline town ${ }^{29}$ and in the region of Campinas city ${ }^{5,22}$, but in this last local, these cercariae were not identified as Cercaria lutzi. Due to extensive amphibian diversity in water collections, these animals are common hosts in many trematode lifecycles. On the other hand, the presence of Xiphidiocercarie is important because they are considered a potential method for biological control of larval mosquitoes ${ }^{6,41}$.

The second form found in B. tenagophila belongs to the family Strigeidae; these cercariae had been identified as $C$. caratinguensis, according to RUIZ ${ }^{30}$ and had low prevalence. In São Paulo State $C$. caratinguensis was found only in the Louveira town and also with low prevalence ${ }^{5}$. Birds and mammals are hosts of these trematodes ${ }^{15,32}$. In fact, in the irrigation ditch of the Bonsucesso districts several rats and birds were observed and they can be hosts of this helminth. In this place the lower prevalence $(1.14 \%)$ was of Brevifurcate pharyngeate Clinostomatoide cercaria. These larvae had been identified as Cercaria ocellifera, according to RUIZ ${ }^{30}$. Cercaria ocellifera also was found in low prevalence (3.6\%) in the district of Saboó, Santos town, São Paulo, Brazil $^{30}$. Cercaria ocellifera is probably the larval form of Clinostomum heluans (Braun, 1989) of family Clinostomidae ${ }^{30}$. These aquatic birds' parasites and their metacercariae commonly encysted in fishes and frogs tissues $^{32}$. According to RUIZ ${ }^{30}$ the tadpoles were species Bufo and Hyla sp., which corroborates our animal observations in this snail habitat. Moreover, in this place we observed herons (Ardeidae), which according to NARUTO ${ }^{25}$ is also host of this trematode.

The fourth larval form of trematode found in B. tenagophila was Cercaria blanchardi (larval form of $S$. mansoni). It is the most important for the public health. Foci of active transmission of schistosomiasis have appeared in Brazil, with serious difficulties for control ${ }^{11}$. In the present study, larval form of S. mansoni was found in B. tenagophila in the stream of Vila Sadokim with $7.14 \%$ of prevalence. In this place we observed many rats and they could harbor these parasites. Nevertheless, we cannot exclude the possibility of human contact, because the place is without protection (fence or wall) and is parallel to an avenue. It is a place of inhabitants' passage (to access the commerce, the bus, the school among others). Moreover, this stream is situated between two industries, meaning constant circulation of employees.

Table 1

Prevalence of trematode infections in Biomphalaria tenagophila sampled from four sites of Guarulhos, São Paulo State, Brazil

\begin{tabular}{|c|c|c|c|c|c|c|c|}
\hline \multirow{2}{*}{ Collection site } & \multirow{2}{*}{$\begin{array}{c}\text { Type of } \\
\text { collection site }\end{array}$} & \multirow{2}{*}{$\begin{array}{l}\text { Number of snails } \\
\text { collected }\end{array}$} & \multirow{2}{*}{ Prevalence $(\%)$} & \multicolumn{3}{|c|}{ Trematode } & \multirow{2}{*}{$\begin{array}{l}\text { Animals usually found } \\
\text { in snail habitats }\end{array}$} \\
\hline & & & & Kinds of cercariae $^{e}$ & Family e,f & Cercariae species ${ }^{\mathrm{f}}$ & \\
\hline \multirow[t]{2}{*}{ Vila Sadokima ${ }^{a}$} & \multirow[t]{2}{*}{ Stream } & \multirow[t]{2}{*}{318} & 7.54 & $\begin{array}{l}\text { Brevifurcate apharyngeate } \\
\text { cercaria }\end{array}$ & Schistosomatidae & $\begin{array}{l}\text { Schistosoma mansoni } \\
\text { (Cercaria blanchardi) }\end{array}$ & \multirow[t]{2}{*}{ Amphibians and rats } \\
\hline & & & 11.94 & Xiphidiocercaria & Plagiorchiidae & Cercaria lutzi & \\
\hline Vila Sadokimb & Irrigation ditch & 64 & 12.50 & Xiphidiocercaria & Plagiorchiidae & Cercaria lutzi & $\begin{array}{l}\text { Amphibians, birds } \\
\text { and rats }\end{array}$ \\
\hline Bonsucesso $^{c}$ & Puddle & 177 & 32.72 & Xiphidiocercaria & Plagiorchiidae & Cercaria lutzi & Amphibians \\
\hline \multirow{3}{*}{ Bonsucesso $^{\mathrm{d}}$} & \multirow{3}{*}{ Irrigation ditch } & \multirow{3}{*}{350} & 4.28 & Strigea cercaria & Strigeidae & Cercaria caratinguensis & \multirow{3}{*}{$\begin{array}{l}\text { Amphibians, birds } \\
\text { and rats }\end{array}$} \\
\hline & & & 10.28 & Xiphidiocercaria & Plagiorchiidae & Cercaria lutzi & \\
\hline & & & 1.14 & $\begin{array}{l}\text { Brevifurcate pharyngeate } \\
\text { Clinostomatoide cercaria }\end{array}$ & Clinostomatidae & Cercaria ocellifera & \\
\hline
\end{tabular}

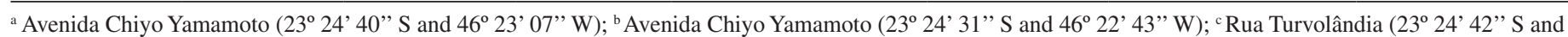
$\left.46^{\circ} 23^{\prime} 18^{\prime \prime} \mathrm{W}\right)$; ${ }^{\mathrm{d}}$ Rua Gino Parenti (23 $24^{\prime} 57^{\prime \prime} \mathrm{S}$ and $\left.46^{\circ} 23^{\prime} 20^{\prime \prime} \mathrm{W}\right){ }^{\mathrm{e}}$ Trematodes types, according to SCHELL ${ }^{32}$; ${ }^{\mathrm{f}}$ Cercariae species, according to RUIZ ${ }^{29,30}$. 
Biomphalaria tenagophila as natural vector was adapted in São Paulo $^{26}$ and the schistosomiasis is still a problem of the public health ${ }^{33,39}$. The foci are a widespread form in many regions of Paraiba do Sul river and Ribeira de Iguape, Metropolitan areas of São Paulo, Campinas, and Baixada Santista, and town nearby of Paranapanema River. Except in the last region, B. tenagophila is responsible for the transmission of schistosomiasis mansoni in other cities ${ }^{39}$.

Biomphalaria tenagophila natural infection from Guarulhos was, mostly, monoespecific (96.56\%). We just observed double infection in $6.55 \%$ mollusk ( $S$. mansoni and $C$. lutzi). These indicators on natural infections validate MACHADO et al. ${ }^{22}$ results. Low prevalence of double infection can be related to the antagonism between two species ${ }^{19,20,34}$. Double infection is more pathogenic when compared to infections of only one trematode species. Snails with multiple infections show high mortality levels ${ }^{34}$. Fluke's development in intermediate host depends on genetic factors likewise environmental factors, which might facilitate eggs and miracid dispersion ${ }^{13,14,42}$. The competition among larvae from different trematode species inside mollusk can reduce both parasite number and snails population ${ }^{3,16,20}$. MACHADO et al. ${ }^{23}$ found that larvae S. mansoni did not develop in B. tenagophila previously infected by Longifurcate cercariae with or without eyespot. They observed that mollusk infected by Echinostome cercariae and Distome cercariae with aculeo were protected from S. mansoni infection at about $73 \%$ to $87 \%$, respectively.

Despite of reduced number of works on helminth identification, interactions are relevant between gastropode and trematode, indicating that may have a huge diversity to be uncovered. Parasitic diseases caused by trematode remains the major problem in public health worldwide. Those illnesses affect animal and human population and are usually related to global warming, awful public health services, migration and, ultimately, geographical distribution of snails transmitters. The fundamental condition to establish a schitosomiasis focus is the fecal contamination by humans or animals at snail farming. Men and other vertebrates around the hydric collection containing snails parasitic by $S$. mansoni enhance trematode cycle and consequently parasites dispersion. Therefore, trematode transmission control is required as well as further studies on helminth biology and physiology.

\section{RESUMO}

\section{Infecção por Schistosoma mansoni e outros trematódeos em Biomphalaria tenagophila (Planorbidae) de Guarulhos, São Paulo, Brasil}

Um total de 909 exemplares de Biomphalaria tenagophila foi coletado de duas regiões em Guarulhos (área Metropolitana de São Paulo, Estado de São Paulo, Brasil) a fim de que fosse verificada infecção por larvas de trematódeos. Em todos os locais de coleta, somente essa espécie foi encontrada e $183(20,13 \%)$ caramujos estavam infectados. Nestes locais, quatro tipos de cercárias foram identificadas com microscópio confocal. Xiphidiocercaria (Cercaria luzti) foi o tipo de cercária mais comum, contribuindo com 76,5\% de toda infecção. Cercárias de Schistosoma mansoni foram encontradas, obtendo um total de $13,11 \%$. Strigea cercaria (Cercaria caratinguensis) e Brevifurcate pharyngeate Clinostomatoide cercaria (Cercaria ocellifera) contribuíram com $8,33 \%$ e $2,22 \%$ de toda infecção, respectivamente. Dupla infecção foi encontrada em doze caramujos, contribuindo com $6,55 \%$ de toda infecção. Em todos os locais, pequenos vertebrados foram encontrados e foi observado contato humano com a água. A presença de caramujos infectados por trematódeos que infectam o homem em grandes cidades tem implicações na saúde pública. Deve-se salientar a importância de mais estudos epidemiológicos e biológicos destes parasitas de importância médica e veterinária.

\section{ACKNOWLEDGEMENTS}

The authors thank Jander Temístocles for reading the manuscript; Edinéia Carvalho de Moraes for editing of images; Alexander Seixas de Souza and Cíntia Batista da Silva for technical assistance. This work received financial support from Fundação de Amparo à Pesquisa do Estado de São Paulo (FAPESP, São Paulo, Brazil).

\section{REFERENCES}

1. AMARAL, R.; TAUIL, P.L.; LIMA, D.D. \& ENGELS, D. - An analysis of the impact of the schistosomiasis control programme in Brazil. Mem. Inst. Oswaldo Cruz, 101 (suppl. 1): 79-85, 2006.

2. ANDERSON, R.M. \& MAY, R.M. - Prevalence of schistosome infections within molluscan populations: observed patterns and theoretical predictions. Parasitology, 79: 63-94, 1979.

3. BASCH, P.F.; LIE, K.J. \& HEYNEMAM, D. - Antagonistic interaction between striged and schistosome sporocyst within a snail host. J. Parasit., 55: 783-788, 1969.

4. BOAVENTURA, M.F.; THIENGO, S.C. \& FERNANDEZ, M.A. - Gastrópodes limnicos hospedeiros intermediários de trematódeos digenéticos no Brasil. Tópicos em Malacologia (XVIII EBRAM), 327-337, 2007.

5. CARVALHO, G.A.; UETA, M.T. \& ANDRADE, C.F. - Búsqueda de xifidiocercarias (Trematoda) en moluscos de agua dulce recolectados en nueve municipios del Estado de São Paulo, Brasil. Bol. chil. Parasit., 56: 3-9, 2001.

6. CARVALHO, G.A.; ANDRADE, C.F. \& UETA, M.T. - Experimental infection of Aedes albopictus (Diptera: Culicidae) Larvae with the xiphidiocercariae of a hematolechid. Mem. Inst. Oswaldo Cruz, 97: 573-578, 2002.

7. CHINGWENA, G.; MUKARATIRWA, S.; KRISTENSEN, T.K. \& CHIMBARI, M. Larval trematode infections in freshwater snails from the highveld and lowveld areas of Zimbabwe. J. Helminth., 76: 283-293, 2002.

8. CHITSUlO, L.; ENGELS, D.; MONTRESOR, A. \& SAVIOLI, L. - The global status of schistosomiasis and its control. Acta trop., 77: 41-51, 2000.

9. COMBES, C. - Trematodes: antagonism between species and sterilizing effects on snails in biological control. Parasitology, 84: 151-175, 1982.

10. CORRÊA, R.R.; PIZA, J.T.; RAMOS, A.S. \& CAMARGO, L.V. - Planorbídeos do Estado de São Paulo. Sua relação com a esquistossomose (Pulmonata, Planorbidae). Arq. Hig. Saúde públ., 27: 139-159, 1962.

11. COURA, J.R. \& AMARAL, R. - Epidemiological and control aspects of schistosomiasis in Brazilian endemic areas. Mem. Inst. Oswaldo Cruz, 99 (suppl. 1): 13-19, 2004.

12. DAVIS, N.E. - Population dynamics of and larval trematode interactions with Lymnaea tomentosa and the potential for biological control of schistosome dermatitis in Bremner Bay, Lake Wanaka, New Zealand. J. Helminth., 72: 319-324, 1998.

13. FERNANDEZ, J.C. \& ESCH, G.W. - Guild structure of larval trematodes in the snail Helisoma anceps: patterns and processes at the individual host level. J. Parasit., 77: 528-539, 1991. 
DE MORAES, J.; NASCIMENTO DA SILVA, M.P.; OHLWEILER, F.P. \& KAWANO, T. - Schistosoma mansoni and other larval trematodes in Biomphalaria tenagophila (Planorbidae) from Guarulhos, São Paulo State, Brazil. Rev. Inst. Med. trop. S. Paulo, 51(2): 77-82, 2009.

14. FERNANDEZ, J.C. \& ESCH, G.W. - The component community structure of larval trematodes in the pulmonate snail Helisoma anceps. J. Parasit., 77: 540-550, 1991.

15. FRANDSEN, F. \& CHRISTENSEN, N. - An introductory guide to the identification of cercariae from African freshwater snails with special reference to cercariae of medical and veterinary importance. Acta trop. (Basel), 41: 181-202, 1984

16. FRANDSEN, F. - Control of schistosomiasis by use of biological control of snail hosts with special reference to competition. Mem. Inst. Oswaldo Cruz, 82 (suppl. 4): 129-133, 1987.

17. GRYSEELS, B.; POLMAN, K.; CLERINKS, J. \& KESTENS, L. - Human schistosomiasis. Lancet, 368: 1106-1118, 2006.

18. INSTITUTO BRASILEIRO DE GEOGRAFIA E ESTATÍSTICA - Censo 2007: População recenseada e estimada, segundo os municípios. Brasília, IBGE, 2007.

19. LAFFERTY, K.D.; SAMMOND, D.T. \& KURIS, A.M. - Analysis of larval trematode communities. Ecology, 75: 2275-2285, 1994.

20. LIM, H.K. \& HEYNEMAN, D. - Intramolluscan intertrematode antagonism: a review of factors influencing the host-parasite system and its possible role in biological control. Advanc. Parasit., 10: 191-268, 1972.

21. LOKER, E.S.; MOYO, H.G. \& GARDNER, S.L. - Trematode-gastropod associations in nine non-lacustrine habitats in Mwanza region of Tanzania. Parasitology, 83: 381-399, 1981

22. MACHADO, S.M.P.; CORDEIRO, N.S.; ARTIGAS, P.T. \& MAGALHÃES, L.A. Algumas considerações sobre cercárias naturalmente encontradas em Biomphalaria tenagophila (ORBIGNY, 1835), capturadas em Louveira, SP. Mem. Inst. Butantan, 49: 79-86, 1987.

23. MACHADO, S.M.P.; MAGALHÃES, L.A.; ARTIGAS, P.T.; CORDEIRO, N.S. \& CARVALHO, J.F. - Verificação de antagonismo entre larvas de Schistosoma mansoni e larvas de outros Digenea em Biomphalaria tenagophila, molusco planorbídeo de criadouro natural situado na região de Campinas, SP, Brasil. Rev. Saúde públ. (S. Paulo), 22: 484-488, 1988.

24. MAY, R.M. - Parasitic infections as regulators of animal population. Amer. Sci., 71: $36-45,1983$

25. NARUTO, T. - Guia para identificação de cercárias. São Paulo, SUCEN/Lab. Malacologia, 1984

26. PARAENSE, W.L. \& DESLANDES, N. - Australorbis nigricans as the transmitter of schistosomiasis in Santos, State of São Paulo. Rev. bras. Malar., 8: 235-245, 1956.

27. PHIRI, A.M.; PHIRI, I.K.; CHOTA, A. \& MONRAD, J. - Trematode infections in freshwater snails and cattle from Kafue wetlands of Zambia during a period of highest cattle-water contact. J. Helmith., 81: 85-92, 2007.
28. PREFEITURA MUNICIPAL DE GUARULHOS - Estatísticas e geografia: aspectos populacionais. Guarulhos, Prefeitura Municipal de Guarulhos, 2007.

29. RUIZ, J.M. - Contribuição ao estudo das formas larvárias de trematóides brasileiros. 2. Fauna de Santos, Estado de S. Paulo. Mem. Inst. Butantan, 24: 17-36, 1952.

30. RUIZ, J.M. - Contribuição ao estudo das formas larvárias de trematóides brasileiros. 5. Descrição de três furcocercárias que ocorrem em planorbídeos hospedeiros do Schistosoma mansoni. Mem. Inst. Butantan, 25: 77-89, 1953

31. SANTOS, L.; COSTA, I.B.; FIGUEIREDO, C.C.S.B. \& ALTOMANI, M.A.G. - Primeiro encontro de Biomphalaria straminea Dunker, 1948, no município de Cruzeiro, Vale do Paraíba, Estado de São Paulo, naturalmente infectada por cercárias de Schistosoma mansoni. Rev. Inst. Adolfo Lutz, 40: 165-166, 1980.

32. SCHELL, S.C. - How to know the trematodes. Dubuque, WMC Brown, 1970.

33. SOUZA, D.; CIARAVOLO, R.M.C.; KANAMURA, H.Y. et al. - Esquistossomose mansônica no Estado de São Paulo: aspectos epidemiológicos. Bol. epidem. paul. 18: $2-8,2005$

34. SOUSA, W.P. - Interspecific interactions among larval trematode parasites of freshwater and marine snails. Amer. Zool., 32: 583-592, 1992.

35. TELES, H.M.S. - Distribuição de Biomphalaria tenagophila e B. occidentalis no Estado de São Paulo, Brasil. Rev. Saúde públ. (S. Paulo), 23: 244-253, 1989.

36. TELES, H.M.S. - Distribuição geográfica das espécies dos caramujos transmissore de Schistosoma mansoni no Estado de São Paulo. Rev. Soc. bras. Med. trop., 38: 426-432, 2005

37. TELES, H.M.S. \& VAZ, J.F. - Distribuição de Biomphalaria glabrata (Say, 1818) (Pulmonata, Planorbidae) no Estado de São Paulo, Brasil. Rev. Saúde públ. (S. Paulo), 21: 508-512, 1987

38. TELES, H.M.S.; HIRAMOTO, R.M.; OLIVEIRA, J.C.N. \& AVEIRO, J.A. - Ocorrência de vetores da esquistossomose mansônica no litoral norte do Estado de São Paulo. Cadern. Saúde públ. (Rio de J.), 19: 1887-1891, 2003.

39. TELES, H.M.S.; CIARAVOLO, R.M.C. \& LIMA, V.L.C. - Controle da esquistossomose mansônica no Estado de São Paulo. Bol. epidem. paul., 3 (supl. 1): 19-26, 2006.

40. TIBIRIÇÁ, S.H.C.; BRESSA, E.C.A.; MITTHEROFHE, A. et al. - Biomphalaria spp. (Preston, 1910) snails in the municipality of Juiz de Fora, Zona da Mata Mineira Mesoregion, State of Minas Gerais, Brazil. Mem. Inst. Oswaldo Cruz, 101 (suppl 1): $179-184,2006$

41. VENKATESWARA RAO, P.; RAMESH BABU, G.; GURAPPA, K. \& GIRI KUMAR, A. - Larval mosquito control through deployment of xiphidiocercariae. J. Invert. Path., 46: 1-4, 1985.

42. WILLIAMS, J.A. \& ESCH, G.W. - Infra- and component community dynamics in the pulmonate snail Helisoma anceps, with special emphasis on the hemiurid trematode Halipegus occidualis. J. Parasit., 77: 246-253, 1991.

Received: 26 May 2008

Accepted: 6 February 2009 